\title{
HCMV pUS28 initiates pro-migratory signaling via activation of Pyk2 kinase
}

\author{
Jennifer Vomaske1, Susan Varnum², Ryan Melnychuk', Patricia Smith', Ljiljana Pasa-Tolic², \\ Janani I Shutthanandan², Daniel N Streblow ${ }^{1 *}$
}

\begin{abstract}
Background: Human Cytomegalovirus (HCMV) has been implicated in the acceleration of vascular disease and chronic allograft rejection. Recently, the virus has been associated with glioblastoma and other tumors. We have previously shown that the HCMV-encoded chemokine receptor pUS28 mediates smooth muscle cell (SMC) and macrophage motility and this activity has been implicated in the acceleration of vascular disease. pUS28 induced SMC migration involves the activation of the protein tyrosine kinases (PTKS) Src and Focal adhesion kinase as well as the small GTPase RhoA. The PTK Pyk2 has been shown to play a role in cellular migration and formation of cancer, especially glioblastoma. The role of Pyk2 in pUS28 signaling and migration are unknown.

Methods: In the current study, we examined the involvement of the PTK Pyk2 in pUS28-induced cellular motility. We utilized in vitro migration of SMC to determine the requirements for Pyk2 in pUS28 pro-migratory signaling. We performed biochemical analysis of Pyk2 signaling in response to pUS28 activation to determine the mechanisms involved in pUS28 migration. We performed mass spectrometric analysis of Pyk2 complexes to identify novel Pyk2 binding partners.

Results: Expression of a mutant form of Pyk2 lacking the autophosphorylation site (Tyr-402) blocks pUS28mediated SMC migration in response to CCL5, while the kinase-inactive Pyk2 mutant failed to elicit the same negative effect on migration. pUS28 stimulation with CCL5 results in ligand-dependent and calcium-dependent phosphorylation of Pyk2 Tyr-402 and induced the formation of an active Pyk2 kinase complex containing several novel Pyk2 binding proteins. Expression of the autophosphorylation null mutant Pyk2 F402Y did not abrogate the formation of an active Pyk2 kinase complex, but instead prevented pUS28-mediated activation of RhoA. Additionally, pUS28 activated RhoA via Pyk2 in the U373 glioblastoma cells. Interestingly, the Pyk2 kinase complex in U373 contained several proteins known to participate in glioma tumorigenesis.

Conclusions: These findings represent the first demonstration that pUS28 signals through Pyk2 and that this PTK participates in pUS28-mediated cellular motility via activation of RhoA. Furthermore, these results provide a potential mechanistic link between HCMV-pUS28 and glioblastoma cell activation.
\end{abstract}

\section{Background}

Human cytomegalovirus (HCMV) is a beta-herpesvirus able to establish a life-long persistent infection after primary infection has been cleared. Although infection is ubiquitous in the human population, persistent HCMV infection is commonly asymptomatic in healthy, immunocompetent individuals. However, HCMV causes significant disease in immunosuppressed patients and,

\footnotetext{
* Correspondence: streblow@ohsu.edu

'The Vaccine \& Gene Therapy Institute, Oregon Health \& Science University, Beaverton OR 97006 USA

Full list of author information is available at the end of the article
}

despite effective antiviral therapies, HCMV infection is still a significant problem in congenital disease and in bone marrow transplant recipients. Additionally, HCMV has been associated with long-term diseases including the vascular diseases atherosclerosis, restenosis following angioplasty, and chronic allograft rejection following solid organ transplantation [1-4]. Recently, HCMV has been detected in human glioblastomas, and it has been suggested that HCMV exacterbates the progression of this disease [5]. Chemokines and their receptors have been identified as key mediators in chronic inflammatory processes that attend the development of vascular

\section{Ciomed Central}


diseases and play a role in tumor development. Herpesviruses manipulate the host chemokine system by regulating the expression of host chemokines and chemokine receptors as well as by encoding chemokine and chemokine receptor homologues. Indeed, HCMV encodes a CXC chemokine (UL146), a putative CC chemokine (UL128), and four potential chemokine receptors (US27, US28, UL33 and UL78). pUS28 is one of the best characterized chemokine receptors and has been implicated in the development of long-term pathologies associated with HCMV infection, including vascular disease and malignancies [6-10].

pUS28 contains homology to the CC-chemokine receptors [11] and binds to a broad spectrum of $\mathrm{CC}$ chemokine ligands, including RANTES/CCL5, MCP-1/ CCL2, MCP-3/CCL7, and MIP-1ß/CCL4. pUS28 is unusual in that it is able to bind the $\mathrm{CX}_{3} \mathrm{C}$-chemokine Fractalkine/CX3CL1 with high affinity in addition to binding a variety of $\mathrm{CC}$-chemokines [12,13]. Although the N-terminal 22 amino acids of pUS28 have been shown to be essential for binding of both chemokine classes, CC-chemokines fail to compete with CX3CL1 for receptor occupation. Mutagenesis studies of pUS28 indicate that different $\mathrm{N}$-terminal residues are critical for binding to each chemokine class $[12,14]$. Chemokine binding to pUS28 initiates a variety of cellular signaling pathways [15-18]. Additionally, pUS28 has been shown to signal constitutively in the absence of ligand binding in several transformed cell lines [19]. pUS28 mediated migration of arterial SMC requires binding of the $\mathrm{CC}$-chemokines CCL5 or CCL2 [20], while CX3CL1 inhibits pUS28mediated SMC migration via the CC-chemokines [18]. However, CX3CL1 does actively promote the robust migration of pUS28 expressing macrophages suggesting that pUS28 has a dual function dependent upon the cell type it is expressed in and the local chemokine environment of that cell [18]. The binding of each chemokine ligand class (CC- vs. $\mathrm{CX}_{3} \mathrm{C}$-) results in differential signaling at the level of G-protein coupling to pUS28 [18]. In fact, pUS28 binding to the $\mathrm{CC}$-chemokines promotes SMC migration through the activation of Ga12/13 and the small G-protein RhoA. pUS28-mediated SMC migration can be blocked by expression of a dominant negative RhoA or RhoA effector associated kinase-1 (ROCK-1) [16].

pUS28 signals through the non-receptor tyrosine kinases focal adhesion kinase (FAK) and Src in a ligand-dependent manner, and this activity is required for induction of pUS28-mediated SMC migration. [17]. FAK is comprised of a central kinase domain flanked on one side by an Nterminal FERM (erythrocyte band 4.1-ezrin-radixinmoesin) domain, which is involved in linking FAK to integrins and growth factor receptors and provides regulation of the Tyr-397 autophosphorylation site [21,22].
Additionally, the FERM domain regulates FAK kinase activity via direct interaction with the kinase domain thereby blocking the access of substrates to the catalytic cleft [23]. The F.A.T. (focal adhesion targeting) domain is located C-terminal of the central kinase domain and is comprised of multiple protein-protein interaction motifs. FAK tyrosine phosphorylation following cellular stimulation is enhanced by its association with Src-family PTKs at Tyr-397. pUS28-mediated SMC migration is sensitive to the Src inhibitor PP2 and mutation of the FAK autophosphorylation site at Tyr-397 blocks SMC migration in a dominant-negative fashion. Conversely, a kinase-negative FAK mutant (FAK R454K) had no effect on pUS28mediated SMC migration [17] suggesting that FAK acts as a protein scaffold rather than an active kinase in the signaling cascade leading to SMC migration.

Proline-rich Tyrosine kinase 2 (Pyk2), also a nonreceptor tyrosine kinase, is highly related to FAK and plays an important role in cell motility [24]. Recently, Pyk2 has been shown to be involved in the CCR5mediated chemotaxis of dendritic cells via binding of HIV-1 gp120 [25]. In addition, Pyk2 is critical for Angiotensin II (AngII)-mediated migration of vascular SMC (VSMC), in which Pyk2 mediates activation of RhoA and its effector kinase ROCK via phosphorylation of PDZ-Rho-GEF [26,27].

FAK and Pyk2 share an overall 45\% sequence homology with $60 \%$ identity within the catalytic domain and also have analogous sites for tyrosine phosphorylation and Src binding [28]. Despite their striking sequence similarity, it is becoming increasingly clear that these molecules play very different roles in signaling cascades leading to cellular migration. Pyk2 is expressed in cells of the brain, hematopoetic cells, osteoblasts, some types of epithelium, SMC and fibroblasts [24]. Unlike FAK, Pyk2 activation has a significant dependence on intracellular calcium levels [28,29]. Calcium-mediated regulation of Pyk2 activity proceeds via binding of $\mathrm{Ca} 2$ +/calmodulin to the Pyk2 FERM domain, allowing homodimerization and autophosphorylation at Tyr-402 [30]. Autophosphorylation of Pyk2 is believed to be a critical initial step in the activation of Pyk 2 via the recruitment of Src to the phosphorylated Tyr-402 site, resulting in further tyrosine phosphorylation of Pyk2 $[31,32]$. However, Pyk2 activation can proceed by both Src-dependent [31,33-35] and Src-independent [36,37] mechanisms. Additionally, Pyk2-mediated phosphorylation of paxillin has been demonstrated to be independent of Tyr-402 autophosphorylation in SYF cells [32]. Collectively these data demonstrate that Tyr-402 autophosphorylation is not absolutely required for Pyk2 activity. While Pyk2 can partially compensate for the lack of FAK in fibroblasts derived from FAK-/- mouse embryos, Pyk2 alone is not sufficient to reconstitute a migratory 
phenotype in these cells [34]. Pyk2 and FAK interact in signaling events leading to cellular migration [38-41], but the relationship between these two proteins remains poorly defined and appears to be highly signal and cell context-specific Additionally, phosphorylation kinetics differ between the two proteins [37].

Here, we examined the involvement of Pyk2 in pUS28-induced signaling and SMC migration. Pyk2 is activated in SMC expressing pUS28 following the addition of ligand in a calcium-dependent manner. Expression of the autophosphorylation site mutant of Pyk2 (F402Y) blocks SMC migration in a dominant-negative fashion by preventing RhoA activation, while the kinaseinactive mutant has no effect on migration. Pyk2 forms an active kinase complex containing several novel Pyk2 binding proteins in CCL5 stimulated SMC expressing pUS28. Suprisingly, the autophosphorylation null mutant Pyk2 F402Y did not abrogate the formation of an active Pyk2 kinase complex but did prevent the pUS28-mediated activation of RhoA. Lastly, we demonstrate the pUS28-mediated activation of RhoA via Pyk2 also occurs in U373 glioblastoma cells. The Pyk2 kinase complex in U373 is distinct from the complex observed in RSMC and contains a number of proteins known to participate in glioma tumorigenesis. These results provide a potential mechanistic link between pUS28 signaling and glioma pathogenesis.

\section{Methods}

\section{Cell Lines}

The life-extended telomerized pulmonary artery SMC line, PAT1 [16] were maintained in Medium 199 supplemented with $20 \%$ fetal calf serum (FCS) and penicillinstreptomycin-L-glutamine (PSG; Gibco). For migration experiments described below, PAT1 cells were utilized between passage 5 and 30 post-telomerization. Mouse FAK-/- fibroblasts were maintained on gelatin coated culture dishes in Dulbecco's modified Eagle's Medium (DMEM) supplemented with 10\% FCS, PSG, non-essential amino acids (Cellgro), and G418 (Sigma; $500 \mu \mathrm{g} / \mathrm{ml}$ ) as previously described $[34,42]$. FAK-/- cells used in experiments were between passage 5 and 15 . Primary F344 rat SMC (RSMC) were maintained in Dulbecco's modified Eagle's Medium (DMEM) with 10\% FCS and PSG. RSMC were used between passage 5 and 20. U373 glioblastoma cells were maintained in DMEM supplemented with $10 \%$ FCS and PSG. U373 were used between passage 5 and 20 .

\section{Reagents}

Recombinant human CCL5 was purchased from R\&D Systems and BAPTA-AM was from Sigma-Aldrich (A1076). Anti-Pyk2 (N-19), anti-phospho-402-Pyk2, anti-myc (9E10), anti-RhoA and anti-HA (F-7) antibodies were purchased from Santa Cruz Biotechnology. Secondary anti-mouse, anti-goat and anti-rabbit horseradish peroxidase (HRP)-conjugated antibodies were purchased from Amersham. Goat anti-mouse Alexa Fluor-488 was purchased from Molecular Probes (A11017).

\section{Adenovirus Construction}

The adenovirus expressing pUS28-HA was previously described $[20,43,44]$. Myc-tagged Pyk2 WT, Pyk2 A457K (kinase inactive mutant) or Pyk2 F402Y (autophosphorylation mutant) [34] were constructed by cloning of the cDNA into pAdTet7, which contains the tet-responsive enhancer within a minimal CMV promoter followed by the SV40 late poly(A) cassette. Recombinant adenoviruses were produced by co-transfection of 293 cells expressing the Cre-recombinase with pAdTet7 constructs and adenovirus DNA (Ad5$\Psi 5$, an E1A/E3-deleted adenovirus genome) [45]. Recombinant adenoviruses were expanded on 293-Cre cells and the bulk stocks were titered on 293 cells by limiting dilution. Gene expression was driven by coinfection with an adenovirus expressing the Tet-off transactivator (Ad-Trans) [20].

\section{SMC migration assay}

Cell migration assays were performed as previously described [20]. PAT1 cells were infected with HCMV (MOI 10) for 2 hrs followed by co-infection with AdTrans and Ad-Pyk2 (WT, A457, F402Y) at MOI of 50 for an additional 2 hrs. Subsequently, the transwells were transferred to new 12-well plates containing fresh medium with CCL5 (50 $\mathrm{ng} / \mathrm{ml}$ ) added to the lower chamber. Cells migrating into the lower chamber were counted at 48-72 hours post-infection (hpi) using a Nikon TE300 microscope at magnification 10×. Experiments were performed in at least triplicate wells and ten random fields were read in each well. The average number of cells per well was determined by multiplying the average number of cells per $10 \times$ field by the number of fields per well. Mean and standard deviation were calculated. Pyk2 recombinant protein levels were monitored by western blotting and equalized by adjusting the adenoviral vector MOI accordingly.

\section{Immunofluorescence}

Subcellular localization of adenovirus-expressed proteins was visualized by fixing adenovirus-infected SMC in 4-well chamber slides (Nunc Lab-Tek) at $24 \mathrm{hpi}$ in $2 \%$ paraformaldehyde for $15 \mathrm{~min}$. Cells were then permeablized with PBS containing $0.2 \%$ Saponin and $0.02 \%$ BSA (sapPBS) for $15 \mathrm{~min}$. Anti-myc primary antibody was diluted 1:500 in sapPBS and cells were incubated for $1 \mathrm{hr}$ at room temperature (r.t.), washed twice with 
sapPBS, and incubated with goat anti-mouse Alexa Fluor-488 diluted 1:1000 in sapPBS for $30 \mathrm{~min}$ at r.t. After two more washes in sapPBS cells were visualized on a Deltavision deconvolution fluorescence microscope (Applied Precision).

\section{Pyk2 Y402 Phosphorylation Assay}

FAK-/- or U373 cells plated onto 6-well culture dishes at $50 \%$ confluence were serum-starved for $6 \mathrm{hrs}$. The cells were infected with Ad-Trans and Ad-pUS28 at MOI 150 with Ad-Pyk2 or Ad-Pyk2 F402Y at MOI 50 and placed in serum free medium. For calcium chelation assays, cells were pre-treated with $50 \mu \mathrm{M}$ BAPTA-AM for $30 \mathrm{~min}$ prior to stimulation. At $16 \mathrm{hpi}$, the cells were stimulated with CCL5 (40 ng/ml) and then scraped in $2 \times$ Laemmeli's Sample Buffer. Unboiled samples were loaded on $10 \%$ SDS-PAGE. The gels were transferred to Immobilon-P membranes then blocked in PBS containing 3\% milk + $0.1 \%$ Tween 20 for 15 min at r.t. The primary anti-Phospho-Y402 Pyk2 rabbit polyclonal antibody was added at 1:1000 dilution in blocking buffer for $1 \mathrm{hr}$ at r.t. The blots were washed with TBS-Tween buffer $(10 \mathrm{mM}$ Tris $\mathrm{pH}$ 7.2, $100 \mathrm{mM} \mathrm{NaCl}, 0.2 \%$ Tween-20). The secondary antibody (goat anti-rabbit conjugated to HRP) was added at 1:20,000 dilution in blocking buffer for $30 \mathrm{~min}$ at r.t. After washing 3 times with TBS-Tween buffer and incubation with ECL reagents, the blots were visualized by autoradiography. Blots were dried to inactivate the HRP secondary reagent and then reprobed as above with antiPyk2 goat polyclonal antibody at 1:1000 dilution in blocking buffer followed by secondary donkey anti-goat conjugated to HRP at 1:100,000 dilution.

\section{RhoA Activation Assay}

FAK-/- or U373 cells plated onto 6-well culture dishes at $50 \%$ confluence were serum-starved for $6 \mathrm{hrs}$. The cells were infected with Ad-Trans only or co-infected with Ad-Trans and Ad-pUS28 at MOI 150 with or without Ad-Pyk2 or Ad-Pyk2 F402Y at MOI 50 and placed in serum free medium. After $16 \mathrm{hrs}$, the cells were stimulated with CCL5 $(40 \mathrm{ng} / \mathrm{ml})$ and then scraped in equal volumes modified RIPA buffer $(10 \mathrm{mM}$ Tris pH7.4, $150 \mathrm{mM} \mathrm{NaCl}, 1 \mathrm{mM}$ EDTA, $1 \%$ Triton X-100, $1 \%$ Sodium Deoxycholate, $0.1 \%$ SDS) containing protease inhibitor cocktail (100 mM AEBSF, $80 \mu \mathrm{M}$ aprotinin, $1.5 \mathrm{mM}$ E-64, $2 \mathrm{mM}$ leupeptin hemisulfate, and $1 \mathrm{mM}$ pepstatin A) at 0 (unstimulated), 2.5, 5, or 10 minutes post-stimulation. Cell lysates were homogenized via sonication, then incubated with $20 \mu \mathrm{l}$ Rho Assay Reagent (Rhotekin-RBD-GST Agarose; Upstate) for $1 \mathrm{hr}$ at $4^{\circ} \mathrm{C}$, then washed 3 times with $1 \mathrm{ml}$ of RIPA. The final bead pellet was resuspended in $40 \mu \mathrm{l}$ of $2 \times$ Laemmli's sample buffer, boiled and then run on $10 \%$ SDS-PAGE. The gels were transferred to Immobilon-P membranes then blocked in blocking buffer (PBS containing 3\% Milk + 0.1\% Tween 20) for 15 min at r.t. The primary anti-RhoA mouse monoclonal antibody was added at 1:1000 dilution in blocking buffer for $1 \mathrm{hr}$ at r.t. The blots were washed with TBS-Tween buffer. The secondary antibody (goat anti-mouse conjugated to HRP) was added at 1:40,000 dilution in blocking buffer for $30 \mathrm{~min}$ at r.t. After washing 3 times with TBSTween buffer and incubation with ECL reagents, the blots were visualized by autoradiography.

\section{Pyk2}

In Vitro Kinase Assays. In vitro kinase assays were performed on on immunoprecipitated Pyk2 from F344 aortic RSMC. Cells were plated in $10 \mathrm{~cm}$ culture dishes and serum starved for $24 \mathrm{hrs}$. The RSMC were co-infected with Ad-Trans and Ad-Pyk2 or Ad-Pyk2 F402Y at an MOI of 50 with or without Ad-pUS28 at an MOI of 150. After 16 hrs, the cells were stimulated with recombinant human CCL5 $(40 \mathrm{ng} / \mathrm{ml})$ and then harvested at times 0 (unstimulated), 2.5, 5, 10, and 15 minutes post ligand addition. Cells were rinsed in PBS and lysed in modified RIPA containing protease inhibitor cocktail and $200 \mu \mathrm{M}$ sodium orthovanadate. Total Pyk2 was immunoprecipitated using mouse anti-myc tag monoclonal antibody and Protein-A/ G conjugated agarose beads (Santa Cruz Biotechnology). Precipitation reactions were washed one time in Tritononly lysis buffer (modified RIPA without sodium deoxycholate and SDS), two times in HNTG buffer (50 mM HEPES, 150 mM NaCl, 1\% Triton, 10\% Glycerol, pH 7.4), and two times in kinase buffer (20 mM HEPES, $10 \mathrm{mM}$ $\mathrm{MgCl}_{2}, 10 \mathrm{mM} \mathrm{MnCl}$, $150 \mathrm{mM} \mathrm{NaCl}, 10 \%$ Glycerol pH 7.4) and then resuspended in $50 \mu$ l kinase buffer plus 10 $\mu \mathrm{Ci}{ }^{32} \mathrm{P}-\gamma$-ATP (Perkin-Elmer). The kinase reaction was allowed to proceed for 30 minutes at r.t. then stopped by the addition of $2 \times$ Laemmeli's sample buffer. After boiling for 5 minutes, the reactions were run on $10 \%$ SDS-PAGE and transferred to Immobilon-P membranes. The incorporation of ${ }^{32} \mathrm{P}$-g-ATP was visualized via autoradiography. After allowing radioactivity to decay, the membranes were further analyzed via western blot as above for the presence of Pyk2-myc and pUS28-HA.

\section{Preparation of Pyk2 Complexes for Proteomics Analysis}

Proteomics analysis was performed on immunoprecipitated Pyk2 from F344 aortic RSMC or U373 glioblastoma cells. Cells were plated in $15 \mathrm{~cm}$ culture dishes. The RSMC were serum starved for $24 \mathrm{hrs}$ prior to coinfection with Ad-Trans and Ad-Pyk2 at an MOI of 50 with or without Ad-pUS28 at an MOI of 150. After $16 \mathrm{hrs}$, the cells were stimulated with recombinant human CCL5 $(40 \mathrm{ng} / \mathrm{ml})$ and then triplicate dishes were harvested at times 0 (unstimulated), 5, 10, 15, 30 and 60 minutes post ligand addition. Cells were rinsed in 
PBS and lysed in modified RIPA containing protease inhibitor cocktail and $200 \mu \mathrm{M}$ sodium orthovanadate. Total Pyk2 was immunoprecipitated using mouse antimyc tag monoclonal antibody and Protein-A/G conjugated agarose beads (Santa Cruz Biotechnology). Precipitation reactions were washed twice with RIPA. Pyk2 and associated proteins were eluted with $200 \mu \mathrm{l}$ of Pierce Gentle Ag/Ab Elution buffer. Triplicate eluates were combined and the samples were sequenced by tandem mass spectrometry analysis at the EMSL user facility at Pacific Northwest National Laboratories.

\section{Tryptic digestion of Pyk2 Complexes}

Proteins from the Pyk2 complexes were desalted and concentrated with Amicon ultra filtration units (Millipore, Billerica, MA). Protein concentration was determined using BCA protein assay (Thermo Scientific) and the concentrated protein was denatured by the addition of trifluoroethanol (TFE) to a final concentration of $50 \%$ and heating to $37^{\circ} \mathrm{C}$ for $60 \mathrm{~min}$. Denatured proteins were reduced with DTT (2 $\mathrm{mM}$ final concentration) and diluted fivefold with $50 \mathrm{mM} \mathrm{NH4HCO3.} \mathrm{Methylated,} \mathrm{sequencing-}$ grade porcine trypsin (Promega, Madison, WI) was added at a substrate-to-enzyme ratio of 50:1 (mass to mass) and incubated at $37^{\circ} \mathrm{C}$ for $3 \mathrm{hrs}$. The peptides were concentrated with a speed vac and stored at $80^{\circ} \mathrm{C}$ until analysis.

\section{Tandem mass spectrometric analysis of peptides}

Peptide samples were analyzed using an automated custom built capillary LC system containing a four capillary column system (Livesay et al, Anal Chem 2008, vol 80, page 294). Eluate from the LC was coupled directly to a hybrid linear ion-trap-orbitrap (LTQ_Orbitrap, Thermo Electron Corp.). The reverse-phase capillary column was prepared by slurry-packing 3-micron Jupiter C18 bonded particles (Phenomenex, Torrence, CA) into a 65 cm long, 75-micron-inner diameter fused silica capillary (Polymicro Technologies, Phoenix, AZ). After peptide loading onto the column, the mobile phase was held at $100 \%$ A (0.05\% trifluoroacetic acid (TFA) and $0.2 \%$ acetic acid in water) for $20 \mathrm{~min}$, followed by a linear gradient from 0 to $70 \%$ buffer B $(0.1 \%$ TFA in $90 \%$ acetonitrile, $10 \%$ water) over 80 min with a flow rate of $\sim 500 \mathrm{~nL} / \mathrm{min}$. Orbitrap spectra (AGC $1 \times 10^{6}$ ) were collected from $400-2000 \mathrm{~m} / \mathrm{z}$ at a resolution of $100 \mathrm{k}$ followed by data-dependent ion trap tandem mass spectra $\left(\mathrm{AGC} 1 \times 10^{4}\right.$ ) of the six most abundant ions using a collision energy of $35 \%$. The heated capillary was maintained at $200^{\circ} \mathrm{C}$, and the ESI voltage was held at $2.2 \mathrm{kV}$.

\section{SEQUEST analysis}

The SEQUEST algorithm was run on each of the datasets against the human.fasta from the International Protein Index database (version 3.54, 75,419 entries, released January 2009). MS/MS peaks were generated by "extract_msn.exe," part of the SEQUEST software package. A peptide was considered to be a match by using a conservative criteria set developed previously by Yates and coworkers [45]. Briefly, peptides were retained if they met the following criteria: 1). SEQUEST DelCN value of $\geq 0.1$ and 2 ). SEQUEST correlation score (Xcorr) $>1.9$ for charge state $1+$ and fully tryptic; Xcorr $>2.2$ for charge state $2+$ and fully or partially tryptic; Xcorr $>3$ for charge state $2+$ regardless of tryptic state; Xcorr $>3.75$ for charge state $3+$ for fully or partially tryptic.

\section{Results}

Pyk2 Autophosphorylation is Required for pUS28mediated SMC Migration

In order to establish the involvement of Pyk2 in pUS28-mediated SMC migration, we constructed a panel of adenovirus vector expressing myc-tagged versions of wild-type Pyk2 (Pyk2-WT), an autophosphorylation null mutant (Pyk2-F402), and a kinase-inactive mutant (Pyk2-A457) (Figure 1A) [34]. These Pyk2 mutant adenoviruses were expressed in human pulmonary artery smooth muscle (SMC) cells. Gene expression was driven by co-infection with the Tet-off transactivator adenovirus (Ad-Trans) and Ad-Trans infection alone is used to control for any non-specific effects of adenovirus infection. All Pyk 2 constructs displayed similar cellular distribution patterns in the cytoplasm and at lamellipodia of growing cells (Figure 1B). As previously described, human SMC cells infected with HCMV migrated in response to CCL5 $[20,46]$ (Figure 1C). Expression of Pyk2-WT produced similar levels of migration compared to Ad-Trans only controls. Surprisingly, co-infection with adenovirus producing kinase-inactive Pyk2 (Pyk2-A457) did not abrogate HCMV-mediated SMC. In contrast, expression of a mutant Pyk2 that lacks the Tyr-402 autophosphorylation site (Pyk2-F402) acted as a dominant negative inhibitor of HCMV-mediated SMC migration, causing a $60 \%$ reduction in SMC migration compared to HCMV-infected SMC expressing Pyk2WT (Figure 1C). These results demonstrate that Pyk2 kinase activity is dispensable for pUS28-mediated SMC migration and suggest that the primary role of Pyk2 in the pro-migratory signaling cascade in these cells is to act as a signaling scaffold for the activation of Src kinase [31].

\section{pUS28 Signaling leads to Phosphorylation of Pyk2 at Y402}

In order to further characterize the role of Pyk2 in pUS28-mediated cellular migration, we examined phosphorylation of Pyk2 at Y402 in Ad-pUS28 infected 


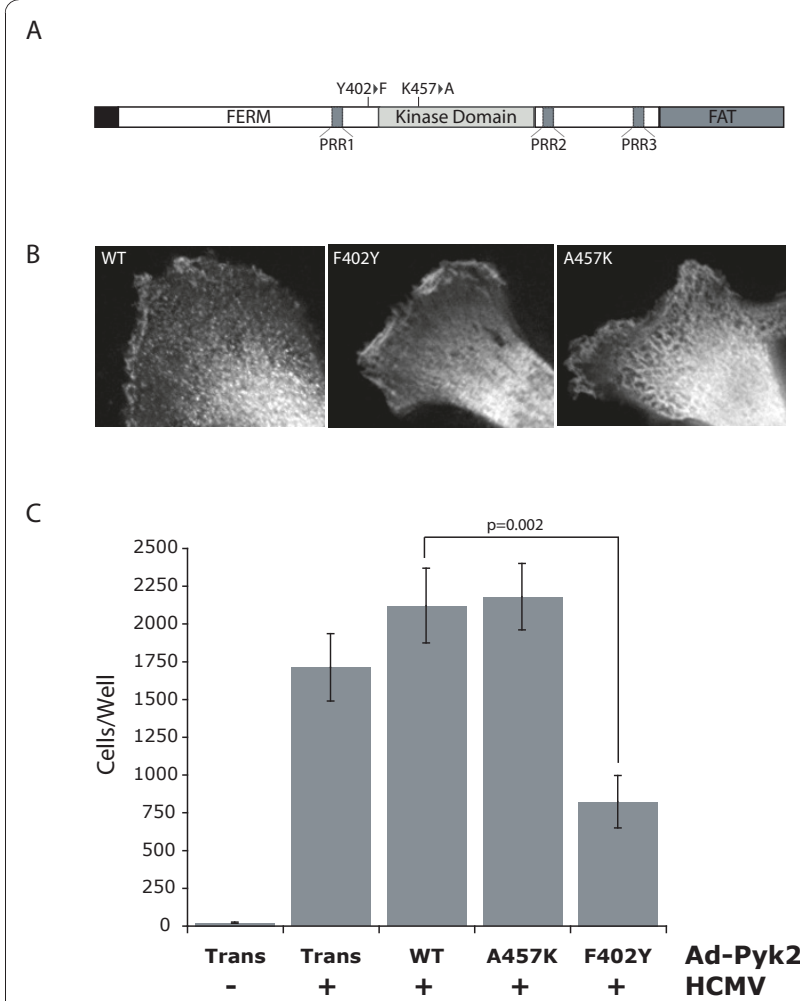

Figure 1 Pyk2 Autophosphorylation Mutant Inhibits HCMVmediated SMC. (A) Schematic of Pyk2 domain structure with A457K and F402Y mutations annotated. (B) Sub-cellular localization of myc-tagged adenovirus constructs was determined via indirect immunofluorescence staining for the myc epitope. From left AdPyk2 WT, Ad-Pyk2-F402Y and Ad-Pyk2-A457K in lamellipodia of adenovirus-infected PAT1 SMC. Gene expression was driven my coinfection with an adenovirus expressing the Tet-off transactivator (Ad-Trans) (C) SMC migration assays were performed on PAT1 SMC co-infected with HCMV at MOI 10 and adenoviruses expressing control Ad-Trans only or Ad-Trans+Pyk2-WT, Pyk2-A457K, or Pyk2F402Y at $\mathrm{MOI} 50$ in transwell chambers. At 2 hrs post-infection fresh medium containing $50 \mathrm{ng} / \mathrm{ml} \mathrm{CCL5}$ was added to the bottom chamber and cells were allowed to migrate for $48 \mathrm{hrs}$. Migrated cells in the lower chamber were counted via light microscopy. For each condition, $\mathrm{n}=6$ from two independent experiments.

mouse fibroblasts lacking FAK (FAK-/-). FAK-/- cells are known to have elevated levels of endogenous Pyk2, partially compensating for the lack of FAK $[34,47]$. We have utilized FAK-/ - for pUS28 signaling assays in previous studies $[17,18]$. FAK-/- exhibit low baseline activation of pro-migratory signaling molecules and are therefore a highly inducible system in which to study these signaling events. Furthermore, using this system we can study pUS28 signaling to Pyk2 independent of FAK.

pUS28-expressing FAK-/- stimulated with CCL5 showed sustained phosphorylation of Pyk2 at Y402. Levels of Pyk2 phosphorlyation were $\sim 2$-fold higher in the presence of pUS28 than control Ad-Trans infected cells similarly stimulated. CCL5 stimulation had a small but quantifiable effect on Pyk2 phosphorylation in FAK-/- cells infected with Trans only, we believe this activation is attributable to the effects of calcium gradients produced by the addition of media upon stimulation (Figure 2A). Pyk2 kinase activity has been shown to be dependent on intracellular calcium levels [28-30]. Therefore, we treated pUS28-expressing FAK-/- with BAPTA-AM to chelate intracellular calcium prior to performing signaling assays. The cells were then stimulated with CCL5 and examined for Pyk2 Y402 phosphorylation via western blot. As expected, chelation of intracellular calcium abrogated phosphorylation of Pyk2 in response to pUS28 signaling (Figure 2B) and prevented Pyk2 activation in Ad-Trans controls (data not shown). We observed a low, but measurable, effect of US28 expression on Pyk2 activity in the absence of ligand (Figure 2A and 2B), which could be attributed to either low-level constitutive signaling or minor effects of endogenously expressed ligands.

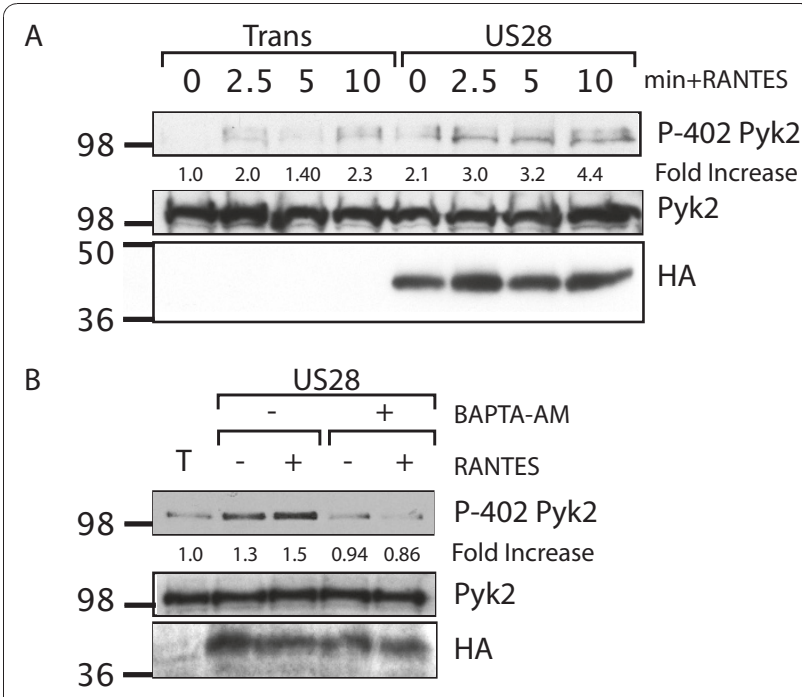

Figure 2 pUS28 Signaling Causes Calcium-Dependent Phosphorylation of Pyk2 at Y402. (A) FAK-/- fibroblasts were infected with Ad-Trans only or Ad-Trans+Ad-pUS28 for 18 hrs. Cells were stimulated with $40 \mathrm{ng} / \mathrm{ml}$ CCL5 for the indicated times and analyzed via western blot with a phospho-specific Pyk2-Y402 antibody or total Pyk2 antibody. (B) Adenovirus-infected FAK-/- were pre-treated for 30 min with BAPTA-AM to chelate intracellular calcium and then stimulated with $40 \mathrm{ng} / \mathrm{ml} \mathrm{CCL5}$ for $5 \mathrm{~min}$. Total cell lysates were analyzed via western blot for phospho-Y402 Pyk2 and total Pyk2. For both experiments, blots were stripped and reprobed to verify pUS28-HA expression. Phospho-specific blots were quantified via densitometry using ImageJ software and are expressed as fold change compared to unstimulated, Ad-Trans infected control. 


\section{pUS28 Signaling Causes formation of a Pyk2-Associated Active Kinase Complex}

We have shown that phosphorylation of Pyk2 at Y402 is required for SMC migration (Figure 1C) and that pUS28 signaling causes phosphorylation at this critical site independent of any pUS28 activation of FAK (Figure 2A). Although activation at the autophosphorylation site is important for Pyk2 function [32], we wanted to further characterize the effect of pUS28 signaling on the activation and function of Pyk2. To accomplish this, we performed in vitro kinase assays on Pyk2 immunoprecipitation reactions. For these experiments we returned to examining Pyk2 signaling in the context of SMC. However, in human SMC endogenous production of pUS28 ligands obscures signaling activation [48]. Therefore, as in previous studies [18], we chose to perform these experiments in primary rat SMC (RSMC) to eliminate this background signaling. Cells were serum starved and co-infected with adenovirus vectors expressing Pyk2WT with or without pUS28-HA. The cells were then stimulated with either $20 \%$ serum, as a positive control for Pyk2 activation, or $40 \mathrm{ng} / \mathrm{ml} \mathrm{CCL} 5$ and harvested at $0,2.5,5,10$ or 15 min post-stimulation. Pyk 2 was then immunoprecipitated from total cell lysates using a monoclonal antibody directed against the myc tag and immunoprecipitated proteins were subjected to in vitro kinase assay. The Pyk2 kinase activity was analyzed via SDS-PAGE and autoradiography. pUS28 signaling promoted the formation of a large kinase complex involving Pyk2 and a number of other interacting phosphoproteins. This protein complex begins to form by $2.5 \mathrm{~min}$ after the addition of CCL5 peaking at 10 min post ligand treatment (Figure 3A and 3C). Plotting the optical density of unstimulated versus 5 min stimulated timepoints using Image J software revealed several pUS28-specific proteins associated with Pyk2 (Figure 3B). When a parallel experiment was performed in the presence of Pyk2-F402Y, a similar kinase complex was observed (data not shown), indicating that Tyr-402 is not critical for formation or maintenance of Pyk2 in an active kinase complex but rather mediates the binding of critical signaling elements necessary for the Pyk2 scaffold to participate in pro-migratory signaling.

\section{Identification of Pyk2 Binding Partners}

We performed proteomics analysis on Pyk2 kinase complexes in order to determine whether pUS28 signaling promotes the association of Pyk2 with novel binding partners. We isolated Pyk2 complexes via immunoprecipitation as described above from RSMC expressing pUS28HA and Pyk2 at 0, 5, 10, 15, 30 or 60 min post-addition of CCL5. As a control for the pUS28-specificity of Pyk2 interactions, we performed identical immunoprecipitation

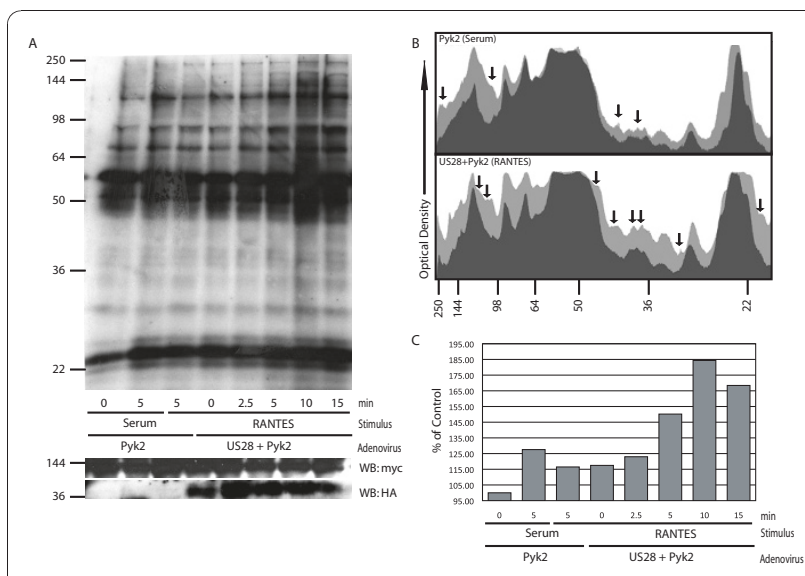

Figure 3 pUS28 Signaling Causes Formation of an Active Kinase Complex Involving Pyk2. SMC were infected with Ad-Trans and Ad-Pyk2 +/- Ad-pUS28 and stimulated with $20 \%$ serum or 40 $\mathrm{ng} / \mathrm{ml} \mathrm{CCL5}$ for indicated times. Pyk2 was immunoprecipitated using myc antibodies. In vitro kinase reactions were performed on immunoprecipitated material and reactions were loaded on SDSPAGE, transferred to immobilon-P membranes and visualized via autoradiography. (A) Autoradiogram of in vitro kinase reactions. Total Pyk2 and pUS28 expression was determined by western blot for myc and HA tags, respectively. (B) Densitometric lane plots of results shown in panel $A$, generated using ImageJ software. The darker curve (overlay) is unstimulated and the lighter curve (background) is 5 min post-stimulation for Pyk2 only stimulated with serum (top) or Pyk2+pUS28 stimulated with CCL5 (bottom). Black arrows indicate bands present only in stimulated samples. Molecular weight markers are shown on the density plot to facilitate comparison to the autoradiogram in panel A. (C) Overall optical density quantification of each lane in Pyk2 in vitro kinase reactions shown in panel $\mathrm{A}$. Values are displayed as percentages compared to unstimulated samples infected with Ad-Trans+Ad-Pyk2.

reactions in RSMC expressing Pyk2 only stimulated with $20 \%$ serum. Bound proteins were analyzed via tandem mass spectrometry. We identified a total of 50 Pyk2 binding partners in RSMC and 24 of these associated with Pyk2 specifically in response to pUS28 expression. Only 6 proteins were specific for Pyk2 in the absence of pUS28 (Figure 4A Table 1 Additional File 1). When we examined the proteins whose Pyk2 association was specifically induced over the signaling timecourse, we determined that 34 proteins associated with Pyk2 in response to pUS28 stimulation by CCL5. In contrast, only 4 proteins were specifically activated by serum stimulation of RMSC expressing Pyk 2 only (Figure 4B). As expected, we identified a number of cytoskeleton structural proteins in our proteomics screen confirming that Pyk2 is directly associated with the cytoskeleton when activated [49] (Table 1 and Additional File 1). We identified several proteins known to interact with Pyk2 in other systems including calmodulin [50] and gelsolin [51]. In support of our hypothesis that Pyk2 serves as a scaffold for pUS28 signaling in RSMC, we found 

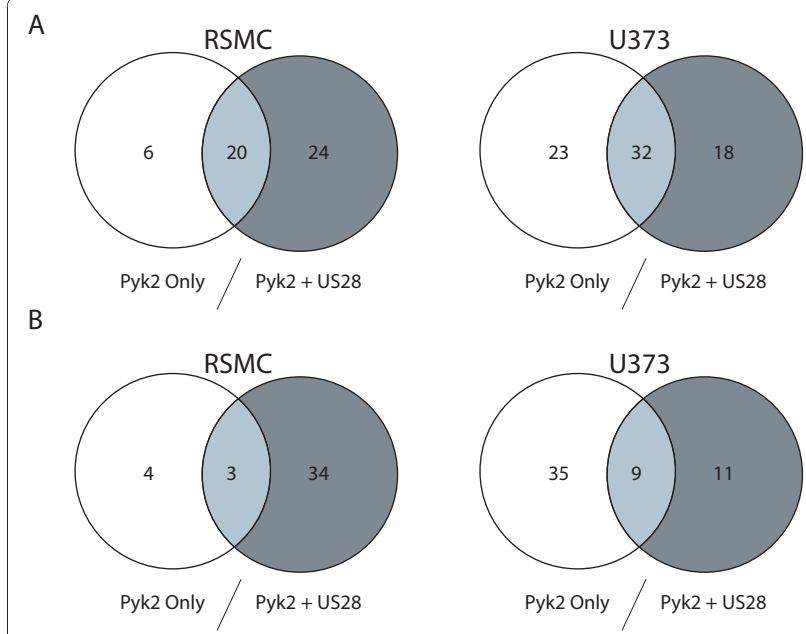

Figure 4 Pyk2-Associated Proteins are Cell-Type and SignalSpecific. SMC or U373 were infected with Ad-Trans and Ad-Pyk2 +/- Ad-pUS28 and stimulated with $20 \%$ serum or $40 \mathrm{ng} / \mathrm{ml} \mathrm{CCL5}$ for $0,5,10,15,30$ or 60 min. Pyk2 was immunoprecipitated using myc antibodies. Pyk2 complexes were analyzed via tandem mass spectrometry. Results shown are proteins identified with $>3$ spectral hits for all peptides. (A) Total hits for Pyk2-associated proteins in RSMC and U373. (B) Proteins for which Pyk2-association was induced over the timecourse of stimulation in RSMC and U373. For data analysis, a protein was considered induced if the average spectral hits for all peptides for timepoints 5, 10, 15, 30 and $60 \mathrm{~min}$ was greater than twice the spectral hits for all peptides in unstimulated cells.

several signaling intermediates associating with Pyk2 over the timecourse. These included a RhoGEF (Trio) known to link G-protein signaling to RhoA activation [52], a regulator of MAPK signaling (KSR-2) [53] as well as a regulator of the SHP-1 tyrosine phosphatase (TFG) [54]. Interestingly, we observed a pUS28 inducible association of Pyk2 with the NF $\kappa$ B precursor p105. Although Pyk2 signaling has been implicated in NFkB activation $[55,56]$, we believe that our data showing $\mathrm{NF} \kappa \mathrm{B}$ p105 present in an activated Pyk 2 complex is novel in the literature. This interaction may provide a secondary, ligand-dependent mechanism for pUS28-mediated activation of $\mathrm{NF} \kappa \mathrm{B}$.

\section{Pyk2 F402Y is Defective in RhoA Activation}

We have previously demonstrated that activation of RhoA is necessary for pUS28-mediated SMC migration [16]. Therefore, we hypothesized that the dominant negative effect of the Pyk2 F402Y mutant is due to a defect in RhoA activation. To test this hypothesis, we performed a RhoA activation assay in cells expressing pUS28 that were stimulated with CCL5. For these experiments, RhotekinRhoA Binding Domain (RBD) conjugated beads were used to specifically pull-down active RhoA from FAK-/- cells expressing Trans only, or Trans + pUS28 with or without Pyk2-WT or Pyk2-F402Y. Percent of RhoA activated was calculated by comparing immunoprecipitated RhoA with total RhoA in the same sample. As expected, within 5 min, CCL5 stimulation of pUS28-expressing FAK-/- results in activation of $68 \%$ of total RhoA compared to a maximum of $27 \%$ activation in control Trans infected cells treated with CCL5 (Figure 5). Overexpression of Pyk2-WT markedly raised baseline activation of RhoA in pUS28 expressing cells and resulted in the activation of $100 \%$ of RhoA at 2.5 min post addition of CCL5. The phenomenon of increased baseline activation of Pyk2 and downstream effectors in the context of overexpression has been observed by others, and appears to be due to the $\mathrm{Ca}^{2}$ ${ }^{+}$-mediated regulation of Pyk2 activity [30]. Conversely, overexpression of Pyk2-F402Y abrogated pUS28-mediated activation of RhoA, resulting in a maximum of $10 \%$ activation over the timecourse of stimulation (Figure 5). We observed some cellular toxicity in samples overexpressing Pyk2 F402Y which resulted in slightly lower total RhoA levels in these samples, but as each sample was internally controlled we believe this has no effect on the data as shown. These results demonstrate that activation of Pyk2 at Y402 is necessary for Pyk2-mediated signaling to RhoA and subsequent signaling leading to SMC migration.

\section{pUS28 Activates Pyk2 in Glioblastoma Cells}

Having established a functional link between pUS28, Pyk2 and migration in SMC, we hypothesized that pUS28 mediates pro-migratory signaling to Pyk2 in other CMV-susceptible cell types. Although HCMV

Table 1 Pyk2 binding partners in pUS28-expressing RSMC

\begin{tabular}{cl}
\hline CATEGORY & PROTEIN(S) IDENTIFIED \\
\hline $\begin{array}{c}\text { Cytoskeleton Structure and } \\
\text { Dynamics }\end{array}$ & $\begin{array}{l}\beta \text {-actin, } \alpha \text { 1-actin, F-actin capping proteins- } \alpha \text { 1, }-\alpha 2^{*}, \text { and - } \beta \text {, Gelsolin [51,72,88,89], Myosin-9, -10, -11, Myosin light } \\
\text { chain-6, Tropomodulin-3 [72], Tropomyosin- } \alpha \text { 1, } \alpha 3, \alpha 4-\beta[72,90,91], \text { Tubulin- } \beta-2 C, \text { Vimentin [92] }\end{array}$ \\
\hline Signal Transduction & Calmodulin [30,50], G-protein subunit $\beta 5[93]$, KSR-2* [53,94], Rhophilin-2* [95], Trio* [52,96], TFG [54] \\
\hline Inflammation and Immunity & Immunoglobulin lambda light chain [97], NF $\kappa B$ p105 \\
\hline Cellular Proliferation & AF-17 [98], RTEL-1* [99]
\end{tabular}

Boldface font indicates proteins identified as Pyk2-associated in multiple cell types.

* indicates proteins identified with low abundance $(<3$ spectral hits on a single peptide). 


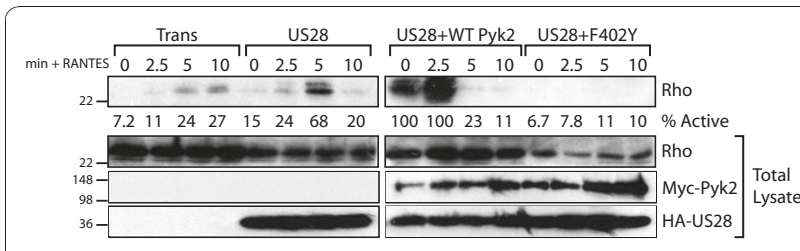

Figure 5 Pyk2-F402Y Blocks pUS28 Signaling to RhoA. FAK-/fibroblasts were infected with Ad-Trans and Ad-pUS28 +/- Pyk2-WT or -F402Y for $18 \mathrm{hrs}$. Cells were stimulated with $40 \mathrm{ng} / \mathrm{ml} \mathrm{CCL5}$ for the indicated times. Lysates were immunoprecipitated with Rhotekin-RBD-GST Agarose and analyzed by western blot for RhoA. Input lysates were analyzed for total RhoA and to confirm adenovirus infection efficiency. The percent active RhoA was quantified via ImageJ densitometry of both IP and total lysate western blots.

infection has been associated with poor clinical outcome in glioblastoma multiforme (GBM) patients, a clear mechanistic link between HCMV and GBM tumorigenesis has not been established [5,46,57]. However, many studies have associated aberrant activation of Pyk2 with increased invasiveness in GBM [41,58-60]. To test whether pUS28 can signal to Pyk2 in a glioma model, we examined phosphorylation of Pyk2 at the Y402 site in pUS28 adenovirus infected U373. Interestingly, we observed pUS28-specific phosphorylation of Pyk2 in U373 in response to both CCL5 and CX3CL1 stimulation (Figure 6A). Interestingly, Pyk2 phosphorylation in response to CX3CL1 stimulation is biphasic, with two separate peaks of phosphorlyation, the first at 2.5 and second at $10 \mathrm{~min}$ post-ligand addition. This biphasic pattern of phosphorylation at the Y402 site has been observed in other systems [37].

We tested the participation of Pyk2 in the pUS28mediated activation of RhoA in this system. Similar to results obtained in FAK-/- fibroblasts, pUS28-specific activation of RhoA is readily observed in U373. pUS28expressing U373 showed 49\% activation of RhoA at 5 min post addition of CCL5. Adenovirus expression of WT Pyk2 resulted in similar activation of RhoA, but altered the timing of RhoA activation such that the peak of RhoA activation was seen at 2.5 min post addition of CCL5. Overexpression of the Pyk2 F402Y mutant prevents pUS28-mediated activation of RhoA resulting in less than $1 \%$ activation of RhoA throughout the timecourse of stimulation (Figure 6B).

In order to compare pUS28-mediated activation of Pyk2 in U373 to that seen in RSMC, we performed proteomics analysis of Pyk2 complexes in U373 (Figure 4 Table 2 and Additional File 2). The conditions for this experiment were the same as the previous experiment in RSMC. Overall, Pyk2 seems to have a greater number of binding partners in U373 underscoring the importance of Pyk 2 in glioma cell biology. A total of 73

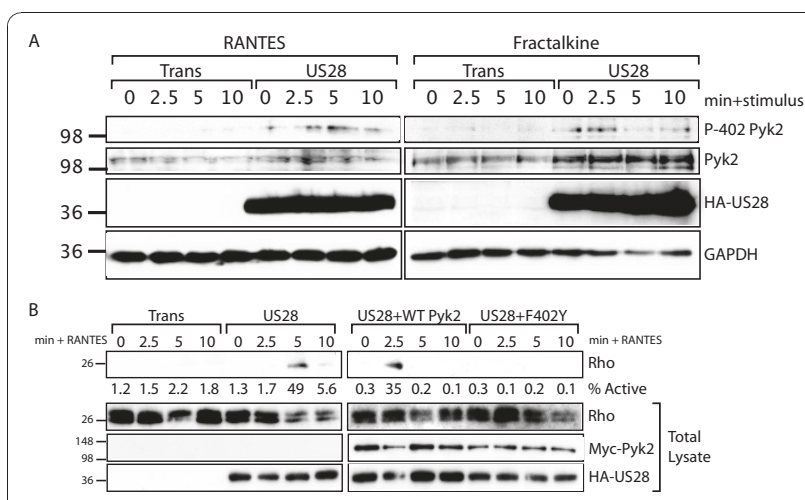

Figure 6 pUS28 Activates Pyk2 and RhoA in U373 Glioblastoma Cells. (A) U373 cells were infected with Ad-Trans or Ad-pUS28 for 18 hrs. Cells were stimulated with $40 \mathrm{ng} / \mathrm{ml} \mathrm{CCL5}$ (left) or $40 \mathrm{ng} / \mathrm{ml} \mathrm{CX3CL1}$ (right) for the indicated times and analyzed via western blot with a phospho-specific Pyk2-Y402 antibody or total Pyk2 antibody. (B) U373 were infected with AdTrans, Ad-pUS28 or Ad-pUS28 + Pyk2 WT or F402Y for 18 hrs. Cells were stimulated with $40 \mathrm{ng} / \mathrm{ml} \mathrm{CCL5}$ for the indicated times. Lysates were immunoprecipitated with Rhotekin-RBD-GST Agarose and analyzed by western blot for RhoA. Input lysates were analyzed for total RhoA and to confirm adenovirus infection efficiency. The percent active RhoA was quantified via ImageJ densitometry of both IP and total lysate western blots.

proteins were found associated with Pyk2 in this system, however only 18 of these were found specifically in pUS28-expressing samples (Figure 4A). In contrast to results seen in RSMC, nearly all of the proteins associated with Pyk2 in U373 were induced by signaling (Figure 4B), revealing low baseline activity of Pyk2 in these cells. Many of the same proteins binding to Pyk2 in response to pUS28 signaling were detected in samples from both cell types (Table $1 \& 2$, boldface text). However, there were a number of proteins that were unique to pUS28 signaling in U373. Importantly, several heat shock proteins of the Hsp70 family (BiP, mortalin and Hsc70) known to be involved in glioma tumorigenesis [61-64] were found to complex with Pyk2 in response to pUS28 signaling. Additionally, several regulators of the Wnt/beta-catenin/Tcf signaling pathway, also implicated in glioma pathogenesis $[65,66]$ are associated with pUS28-activated Pyk2 complexes (Table 2).

\section{Discussion}

In this paper, we examined the ability of the HCMVencoded chemokine receptor pUS28 to activate Pyk2 and determined the role of Pyk2 in pUS28 mediated SMC migration (Figure 7). Pyk2 expression is limited to a subset of cell types in vivo including brain, hematopoetic cells, endothelial cells, SMC and fibroblasts. Interestingly, many of these cell types are capable of undergoing migration events in response to various external stimuli including integrin, growth factor, 
Table 2 Pyk2 binding partners in pUS28-expressing U373

\begin{tabular}{cl}
\hline CATEGORY & PROTEIN(S) IDENTIFIED \\
\hline $\begin{array}{c}\text { Cytoskeleton Structure and } \\
\text { Dynamics }\end{array}$ & $\beta$-actin, $\alpha$ 1-actin, $\alpha$-actin, Nectin-3 [100], Myosin-9, Myosin light chain-6, Tropomyosin- $\alpha 1$ [72,90,91] \\
\hline Signal Transduction & USP6 oncogene* [101], NIM1 kinase* [102], Copine-5* [103], Abl-interactor-2* [104], TFG [54] \\
\hline Inflammation and Immunity & Immunoglobulin lambda light chain [97], NF $\kappa$ B p105 \\
\hline Cellular Proliferation & $\begin{array}{c}\text { TCF-4 [50,65], AF-17 [98], RTEL-1* [99,105,106], N-acetyltransferase-10 [107], Integrator complex subunit 6 } \\
{[108]}\end{array}$ \\
\hline Stress Response & BiP [61,109], Mortalin [62,110], Hsc70 [63,64]
\end{tabular}

Boldface font indicates proteins identified as Pyk2 associated in multiple cell types.

* indicates proteins identified with low abundance ( $<3$ spectral hits on a single peptide).

hormone and chemokine-mediated signals. There is very little consensus in the literature regarding the participation of Pyk2 in such migration events. Indeed, requirements for Pyk2 signaling, and downstream effectors of Pyk2 activation are highly cell type and signal type-specific [28].

\section{Pyk2 and migration in vascular smooth muscle}

Migration of vascular SMC is induced by a variety of stimuli including growth factors, cytokines, extracellular matrix (ECM) components and peptide hormones. Promigratory signaling in SMC is best understood in the context of platelet-derived growth factor (PDGF) binding through receptor tyrosine kinases PDGFR- $\alpha$ and $\beta$. PDGF-mediated migration in SMC is characterized by Src-dependent activation of FAK, RhoA mediated activation of ROCK and subsequent phosphorylation and inhibition of myosin light chain phosphatase as well as activation of various other effector molecules via ERK, p38MAPK and JNK MAPK families [67]. Angiotensin II

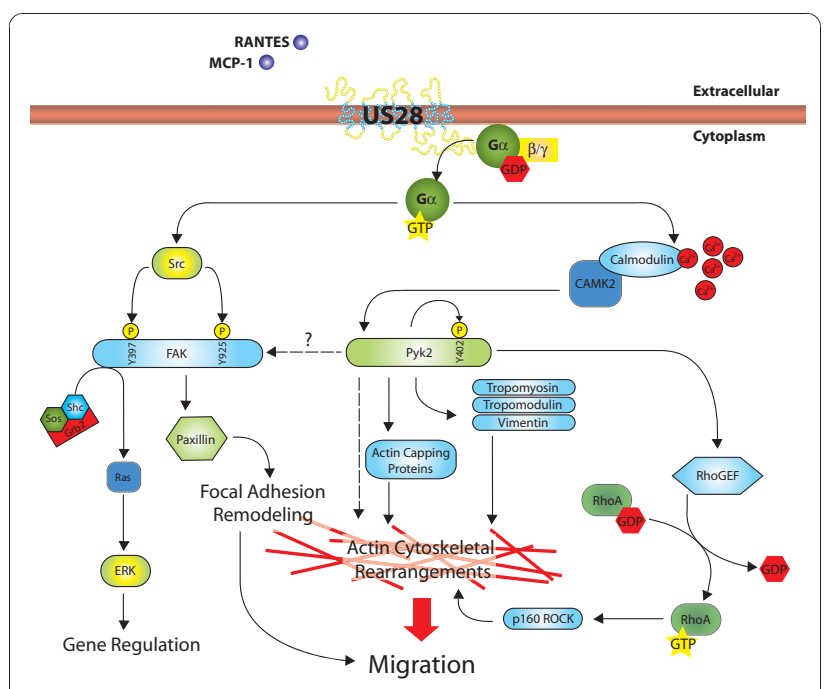

Figure 7 pUS28-mediated Pro-migratory Signaling in SMC. Schematic model for known components of US28-mediated promigratory signaling in response to CC-chemokine ligands.
(Ang II) is another well-studied pro-migratory signal in SMC. Ang II binding to the GPCR angiotensin receptor type 1 (AT-1) initiates the only pro-migratory signaling cascade in SMC previously reported to involve Pyk2 [68]. In this signaling context, Pyk2 is activated by PKC $\delta$ [69] and signals to Rho/ROCK via association with PDZ-RhoGEF [26]. Additionally, Pyk2 has been identified as an essential signaling scaffold linking GPCR signaling to MAP kinase activation via Src activation upon binding to Tyr-402 autophosphorylated Pyk2 [31]. Activation of JNK and ERK MAP kinase pathways are necessary for Ang II-mediated SMC migration [26].

The results presented herein represent the first example of a chemokine-mediated pro-migratory signaling cascade in VSMC involving Pyk2. We have previously demonstrated that chemokine binding to the viral chemokine receptor pUS28 causes SMC migration via a Src-mediated activation of FAK and ERK [17], and the Ga12-mediated activation of RhoA and ROCK [16]. These results refine our understanding of the pUS28 receptor-proximal events leading to the activation of RhoA via the ligand-dependent phosphorylation of Pyk2 at Tyr-402. Pyk2 kinase activity is dispensable for pUS28-mediated migration in SMC, suggesting that Pyk2 participates primarily as a signaling scaffold in pUS28 pro-migratory signaling. We have previously demonstrated that pUS28-induced SMC migration is sensitive to the Src inhibitor PP-2 and that FAK functionally interacts with Src in pUS28-expressing cells stimulated with CCL5. We further demonstrated that Src activation is upstream of FAK in this pathway [17]. Similarly, pUS28 can signal to Pyk2 in FAK-/- fibroblasts suggesting that Pyk2 activation is upstream or independent of FAK in this signaling cascade. Our proteomics analysis of Pyk2 binding partners in the context of pUS28 signaling revealed several novel proteins that shed new insight into the function of Pyk2 in promigratory signaling. In particular, we show that Pyk2 interacts with several tropomyosin (TM) isoforms and the TM interacting protein tropomodulin isoform 3 (Tmod3) in response to pUS28 signaling. These proteins 
are well-characterized regulators of actin polymerization and cytoskeletal dynamics [70]. Tmod3 is broadly expressed in cells with dynamic actin filament structures and is unique among tropomodulin proteins in that, in addition to regulating the capping of actin filament pointed ends, it binds free actin monomers and may regulate the nucleation of new actin filaments [71]. Our discovery of an association of Pyk2 with TM isoforms is novel and particularly intriguing. TM proteins regulate the structure and specific properties of actin filaments but the mechanisms of TM regulation remain obscure [72]. One possible mechanism of TM regulation is phosphorylation. Indeed, the phosphorlyation of TM1 in response to ERK signaling in endothelial cells increases the formation of both actin stress fibers and focal adhesions contributing to increased cellular contractility [73]. Our results suggest that the Pyk2 signaling complex participates in cytoskeleton remodeling via modification of Tmod and TM proteins. Taken together, these results suggest that Pyk2 acts together with Src, FAK and other adaptor molecules to promote pro-migratory signaling and that Pyk2 phosphorylation at Tyr-402, is required for the downstream activation of RhoA. Our finding that the scaffolding activity of Pyk2 is separable from its kinase activity is novel in the literature. In the context of AngII-mediated SMC migration as well as migration of endothelial cells, Pyk2 kinase activity is an essential component of pro-migratory signaling $[26,74]$.

\section{pUS28 signaling and CMV-associated malignancy}

In this paper, we explore the contribution of pUS28 signaling to Pyk2 in migration processes associated with HCMV-mediated vascular disease. However, HCMV has been implicated in other disease processes in which the induction of cellular migration may play a role. In particular, HCMV infection has been associated with several human malignancies including prostate and colon cancers as well as glioblastoma multiforme (GBM) [75]. GBM is the most common and most malignant type of brain cancer and currently has no effective treatment [76]. HCMV DNA is present in over $90 \%$ of human malignant gliomas [1,77], suggesting a role for HCMV in glioma oncogenesis. A recent report has strengthened the connection between HCMV and GBM by demonstrating that vaccination against the HCMV tegument protein pp65 can improve survival in GBM patients [78]. However, the molecular mechanisms of HCMV participation in glioma development remain unclear.

pUS28 signaling has recently been reported to produce a transformed phenotype in transfected NIH-3T3 cells characterized by increased proliferative capacity, and increased expression of the pro-angiogenic marker VEGF. In addition, the study demonstrated that WT HCMV infection of a human glioblastoma cell line
(U373) induces VEGF expression while a pUS28 deletion mutant of HCMV fails to induce VEGF upregulation in glioblastoma cells [10] implicating pUS28 signaling in glioma pathogenesis. However, this study did not explore the contribution of pUS28 ligand binding to the observed phenotypes.

\section{Pyk2 and glioma tumorigenesis}

In addition to its role in vascular remodelling, Pyk2 has been identified as a pro-metastatic and pro-angiogenic molecule in several cancer models including small cell lung cancer $[79,80]$, prostate cancer [81-83] and glioblastoma [41,58-60]. A number of elegant studies by Lipinski et. al. have established roles for Pyk2 and FAK in glioma tumorigenesis both in vitro and in vivo. In these studies, Pyk2 is demonstrated to promote migration and invasion of glioma cells while FAK controls their proliferation. The authors demonstrate that the migratory capacity of individual glioma cell lines can be correlated to the relative levels of Pyk2 expression and activation. Perhaps the most compelling evidence for the role of Pyk2 and FAK in glioma tumor progression utilized an in vivo xenograft model of glioblastoma in mice. In this study, Pyk2 deficient cells were observed to invade only locally and survival was significantly increased when mice were engrafted with Pyk2 or FAK deficient glioma cells compared to mice engrafted with wild-type glioma cells [60]. Our current study and previous work characterizing the pUS28-mediated activation of FAK suggest a mechanism for acceleration of glioma tumor formation by HCMV via pUS28-mediated signaling through the critical mediators of glioma tumor progression, Pyk 2 and FAK. Our results are consistent with existing literature in which the Pyk2 FERM domain is established as a target for reducing glioma cell migration $[58,84]$. Pyk2 undergoes dimerization and autophosphorylation upon FERM domain interaction with Ca2 +/calmodulin [30]. Therefore inhibition of the Pyk2 FERM domain by mutation or antibody targeting may prevent dimerization and phosphorylation of Pyk2 at Tyr-402 thereby preventing the activation of RhoA.

We observed the formation of a cell type specific Pyk2 complex in response to pUS28 signaling in U373 glioblastoma cells. This complex included several proteins previously implicated in glioma tumorigenesis, but never before identified as Pyk2 binding partners. Our data suggests at least two novel mechanisms for the participation of Pyk2 and pUS28 in glioma tumorigenesis. First, we identified TCF-4 and AF-17 binding to Pyk2 in response to pUS28 signaling. Both proteins are members of the Wnt/ $\beta$-catenin signaling pathway that has recently been linked to glioma progression $[65,66]$. Indeed, siRNA mediated inhibition of this pathway decreases glioma proliferation and invasion capacity 
[65]. Interestingly, Pyk2 has been shown to phosphorylate $\beta$-catenin in endothelial cells [85] suggesting that Pyk2 may be involved in the activation of canonical $\beta$-catenin signaling in multiple cell types. Second, we discovered that pUS28 signaling caused Pyk2 to associate with three members of the Hsp70 family of molecular chaperone proteins. Interestingly, all three of these proteins are known to be specifically upregulated in glioma tissue and play various roles in the progression of glioma tumorigenesis [61-63] as well as other cancer models [86]. Mortalin, in particular, is functionally regulated via tyrosine phosphorylation [87]. Our results suggest that Pyk2, or kinases associated with Pyk2 may play a role in regulating the function of multiple Hsp70-family chaperones, thereby contributing to the proliferation and survival of tumor cells.

These findings refine our understanding of the promigratory signaling pathways activated by pUS 28 in SMC and establish Pyk2 as an attractive target for the treatment of $\mathrm{CMV}$-mediated vascular disease because it acts early in the pUS28 pro-migratory signaling cascade and its expression is restricted to a few cell types, reducing the opportunities for off-target effects. Further, these results suggest a role for HCMV pUS28 in pathologies associated with aberrant activation of Pyk2 including some malignancies.

\section{Conclusions}

In this report, we determined the involvement of Pyk2 in pUS28 signaling and cellular migration (Figure 7). We found that Pyk2 autophosphorylation activity, but not kinase activity, is necessary for HCMV-mediated SMC migration. Furthermore, pUS28 signaling causes ligand-dependent phosphorylation of Pyk2 at Tyr-402 independent of pUS28 signaling to FAK. Pyk2 is incorporated into an active kinase complex in CCL5 stimulated SMC expressing pUS28. Pyk2 associates with a number of other proteins in response to pUS28 signaling including kinases, signaling molecules, cytoskeletal proteins, and molecular chaperones. We determined that although the Pyk2 autophosphorylation mutant (F402Y) does not prevent the formation of an activated kinase complex, it exerts a dominant negative effect on SMC migration by preventing the pUS28-mediated activation of the small G-protein RhoA. Importantly, the effect of pUS28 activating Pyk2 is not cell-type specific as we observed comparable activation of Pyk2 and RhoA via pUS28 signaling in U373 glioblastoma cells. This finding suggests that pUS28 signaling to Pyk2 may be important in glioma cell motility. In addition to establishing Pyk2 as a potential target in the treatment of HCMV-mediated vascular disease, and establishing a number of novel Pyk2-associated proteins, these results provide a potential link between pUS28 and CMV-associated malignancy.

\section{Additional material}

\section{Additional file 1: Table S1: Mass Spectrometry Data for Pyk2} Complexes in RSMC. For each Pyk2 associated protein, spectral hits are shown for each unique peptide over the timecourse of stimulation. Total spectral hits per peptide are shown to the right of the timecourse for each condition. Total peptides and spectral hits for each timepoint are shown below the list of peptides for each protein.

Additional file 2: Table S2: Mass Spectrometry Data for Pyk2 Complexes in U373. For each Pyk2 associated protein, spectral hits are shown for each unique peptide over the timecourse of stimulation. Total spectral hits per peptide are shown to the right of the timecourse for each condition. Total peptides and spectral hits for each timepoint are shown below the list of peptides for each protein.

\section{Acknowledgements}

The authors would like to thank David D. Schlaepfer for his generous contribution of the cDNA clones used to make the Pyk2 adenoviruses. This work was supported in part by the National Institutes of Health (NIH) grant HL083194 (to DNS) and HL088603 (to JAN). The proteomics work was performed as part of a Science Theme User Proposal from the Pacific Northwest National Labs William R. Wiley Environmental Molecular Science Laboratory (EMSL) under the theme of Biological Interactions and Dynamics (Project \#30468). EMSL is a national scientific user facility sponsored by the Department of Energy's Office of Biological and Environmental Research and located at Pacific Northwest National Laboratory.

\section{Author details}

1The Vaccine \& Gene Therapy Institute, Oregon Health \& Science University, Beaverton OR 97006 USA. ${ }^{2}$ Pacific Northwest National Laboratories, Richland, WA 99352 USA.

\section{Authors' contributions}

JEV participated in the design of the study, carried out all signaling and immunofluorescence assays, prepared samples for proteomics analysis and drafted the manuscript. SV coordinated the mass spectrometry and participated in MS data analysis. RM developed the RhoA activation assay. PS performed SMC migration assays and helped to edit the manuscript. LPT prepared samples for mass spectrometry and participated in data analysis, JIS participated in MS data analysis, DNS conceived of the study, participated in its design and coordination and helped to draft and edit the manuscript. All authors read and approved the final manuscript.

\section{Competing interests}

The authors declare that they have no competing interests.

Received: 16 April 2010 Accepted: 7 December 2010

Published: 7 December 2010

\section{References}

1. Cobbs CS, Harkins L, Samanta M, Gillespie GY, Bharara S, King PH, Nabors LB, Cobbs CG, Britt WJ: Human cytomegalovirus infection and expression in human malignant glioma. Cancer Res 2002, 62:3347-3350.

2. Melnick JL, Adam E, DeBakery ME: The link between CMV and atherosclerosis. Infect Med 1998, 479-486.

3. Speir E, Modali R, Huang ES, Leon MB, Shawl F, Finkel T, Epstein SE: Potential Role of Human Cytomegalovirus and p53 Interaction in Coronary Restenosis. Science 1994, 265:391-394.

4. Almond PS, Matas A, Gillingham K, Dunn DL, Payne WD, Gores P, Gruessner R, Najarian JS: Risk factors for chronic rejection in renal allograft recipients. Transplant 1993, 55:752-756, discussion 756-757.

5. Scheurer ME, Bondy ML, Aldape KD, Albrecht T, El-Zein R: Detection of human cytomegalovirus in different histological types of gliomas. Acta Neuropathol 2008, 116:79-86.

6. Akter P, Cunningham C, MCSharry BP, Dolan A, Addison C, Dargan DJ, Hassan-Walker AF, Emery VC, Griffiths PD, Wilkinson GW, Davison AJ: Two 
novel spliced genes in human cytomegalovirus. J Gen Virol 2003, 84:1117-1122.

7. Penfold ME, Dairaghi DJ, Duke GM, Saederup N, Mocarski ES, Kemble GW Schall TJ: Cytomegalovirus encodes a potent alpha chemokine. Proc Natl Acad Sci USA 1999, 96:9839-9844.

8. Chee MS, Satchwell SC, Preddie E, Weston KM, Barrell BG: Human Cytomegalovirus Encodes three G Protein-Coupled Receptor Homologues. Nature 1990, 344:774-777

9. Chee MS, Bankier AT, beck S, Bohni R, Browne CM, Cerny R, Horsnell T, Hutchison CA III, Kouzarides T, martignetti JA, et al: Analysis of the proteincoding content of the sequence of human cytomegalovirus strain AD169. In Cytomegaloviruses. Edited by: McDougall JK. Berlin, Heidelberg, New yrok: Springer-Verlag; 1990:125-171

10. Maussang D, Verzijl D, van Walsum M, Leurs R, Holl J, Pleskoff $O$, Michel $D$, van Dongen GA, Smit MJ: Human cytomegalovirus-encoded chemokine receptor US28 promotes tumorigenesis. Proc Natl Acad Sci USA 2006, 103:13068-13073.

11. Gao JL, Murphy PM: Human cytomegalovirus open reading frame US28 encodes a functional beta chemokine receptor. J Biol Chem 1994, 269:28539-28542.

12. Kledal TN, Rosenkilde MM, Schwartz TW: Selective recognition of the membrane-bound $\mathrm{CX} 3 \mathrm{C}$ chemokine, fractalkine, by the human cytomegalovirus-encoded broad-spectrum receptor US28. FEBS Letters 1998, 441:209-214.

13. Kuhn DE, Beall CJ, Kolattukudy PE: The Cytomegalovirus US28 Protein Binds Multiple CC Chemokines with High Affinity. Biochemical and Biophysical Research Communications 1995, 211:325-330.

14. Casarosa P, Waldhoer M, LiWang PJ, Vischer HF, Kledal T, Timmerman H, Schwartz TW, Smit MJ, Leurs R: CC and CX3C chemokines differentially interact with the $\mathrm{N}$ terminus of the human cytomegalovirus-encoded US28 receptor. J Biol Chem 2005, 280:3275-3285.

15. Billstrom MA, Johnson GL, Avdi NJ, Worthen GS: Intracellular Signaling by the Chemokine Receptor US28 during Human Cytomegalovirus Infection. J Virol 1998, 72:5535-5544.

16. Melnychuk RM, Streblow DN, Smith PP, Hirsch AJ, Pancheva D, Nelson JA: Human cytomegalovirus-encoded G protein-coupled receptor US28 mediates smooth muscle cell migration through Galpha12. J Virol 2004, 78:8382-8391.

17. Streblow DN, Vomaske J, Smith P, Melnychuk R, Hall L, Pancheva D, Smit M, Casarosa P, Schlaepfer DD, Nelson JA: Human cytomegalovirus chemokine receptor US28-induced smooth muscle cell migration is mediated by focal adhesion kinase and Src. J Biol Chem 2003, 278:50456-50465.

18. Vomaske J, Melnychuk RM, Smith PP, Powell J, Hall L, DeFilippis V, Fruh K Smit M, Schlaepfer DD, Nelson JA, Streblow DN: Differential ligand binding to a human cytomegalovirus chemokine receptor determines cell typespecific motility. PLoS Pathog 2009, 5:e1000304.

19. Casarosa P, Bakker RA, Verzijl D, Navis M, Timmerman H, Leurs R, Smit MJ: Constitutive signaling of the human cytomegalovirus-encoded chemokine receptor US28. J Biol Chem 2001, 276:1133-1137.

20. Streblow DN, Söderberg-Nauclér C, Vieira J, Smith P, Wakabayashi E, Rutchi F, Mattison $K$, Altschuler $Y$, Nelson JA: The human cytomegalovirus chemokine receptor US28 mediates vascular smooth muscle cell migration. Cell 1999, 99:511-520.

21. Sieg DJ, Hauck CR, llic D, Klingbeil CK, Schaefer E, Damsky CH, Schlaepfer DD: FAK integrates growth-factor and integrin signals to promote cell migration. Nat Cell Biol 2000, 2:249-256.

22. Jacamo RO, Rozengurt E: A truncated FAK lacking the FERM domain displays high catalytic activity but retains responsiveness to adhesionmediated signals. Biochem Biophys Res Commun 2005, 334:1299-1304.

23. Lietha D, Cai X, Ceccarelli DF, Li Y, Schaller MD, Eck MJ: Structural basis for the autoinhibition of focal adhesion kinase. Cell 2007, 129:1177-1187.

24. Gelman IH: Pyk 2 FAKs, any two FAKs. Cell Biol Int 2003, 27:507-510.

25. Anand AR, Prasad A, Bradley RR, Deol YS, Nagaraja T, Ren X, Terwilliger EF, Ganju RK: HIV-1 gp120-induced migration of dendritic cells is regulated by a novel kinase cascade involving Pyk2, p38 MAP kinase and LSP1. Blood 2009, 22;114(17):3588-600.

26. Ohtsu $H$, Mifune $M$, Frank GD, Saito $S$, Inagami T, Kim-Mitsuyama $S$, Takuwa Y, Sasaki T, Rothstein JD, Suzuki H, et al: Signal-crosstalk between Rho/ROCK and c-Jun NH2-terminal kinase mediates migration of vascular smooth muscle cells stimulated by angiotensin II. Arterioscler Thromb Vasc Biol 2005, 25:1831-1836.
27. Ying Z, Giachini FR, Tostes RC, Webb RC: PYK2/PDZ-RhoGEF links Ca2+ signaling to RhoA. Arterioscler Thromb Vasc Biol 2009, 29:1657-1663.

28. Avraham H, Park SY, Schinkmann K, Avraham S: RAFTK/Pyk2-mediated cellular signalling. Cell Signal 2000, 12:123-133.

29. Li X, Earp HS: Paxillin is tyrosine-phosphorylated by and preferentially associates with the calcium-dependent tyrosine kinase in rat liver epithelial cells. J Biol Chem 1997, 272:14341-14348.

30. Kohno T, Matsuda E, Sasaki H, Sasaki T: Protein-tyrosine kinase CAKbeta/ PYK2 is activated by binding Ca2+/calmodulin to FERM F2 alpha2 helix and thus forming its dimer. Biochem J 2008, 410:513-523.

31. Dikic I, Tokiwa G, Lev S, Courtneidge SA, Schlessinger J: A role for Pyk2 and $\mathrm{Src}$ in linking G-protein-coupled receptors with MAP kinase activation. Nature 1996, 383:547-550.

32. Park S-Y, Avraham HK, Avraham S: RAFTK/Pyk2 Activation Is Mediated by Trans-acting Autophosphorylation in a Src-independent Manner. J Biol Chem 2004, 279:33315-33322

33. Cheng JJ, Chao YJ, Wang DL: Cyclic strain activates redox-sensitive proline-rich tyrosine kinase 2 (PYK2) in endothelial cells. J Biol Chem 2002, 277:48152-48157.

34. Sieg DJ, llic D, Jones KC, Damsky CH, Hunter T, Schlaepfer DD: Pyk2 and Src-family protein-tyrosine kinases compensate for the loss of FAK in fibronectin-stimulated signaling events but Pyk2 does not fully function to enhance FAK-cell migration. Embo J 1998, 17:5933-5947.

35. Sorokin A, Kozlowski P, Graves L, Philip A: Protein-tyrosine kinase Pyk2 mediates endothelin-induced p38 MAPK activation in glomerular mesangial cells. J Biol Chem 2001, 276:21521-21528.

36. Le Bouf F, Houle F, Sussman M, Huot J: Phosphorylation of Focal Adhesion Kinase (FAK) on Ser732 Is Induced by Rho-dependent Kinase and Is Essential for Proline-rich Tyrosine Kinase-2-mediated Phosphorylation of FAK on Tyr407 in Response to Vascular Endothelial Growth Factor. Mol Biol Cell 2006, 17:3508-3520.

37. Wu SS, Jacamo RO, Vong SK, Rozengurt E: Differential regulation of Pyk2 phosphorylation at Tyr-402 and Tyr-580 in intestinal epithelial cells: Roles of calcium, Src, Rho kinase, and the cytoskeleton. Cell Signal 2006 18(11):1932-40.

38. Avraham HK, Lee TH, Koh Y, Kim TA, Jiang S, Sussman M, Samarel AM, Avraham S: Vascular endothelial growth factor regulates focal adhesion assembly in human brain microvascular endothelial cells through activation of the focal adhesion kinase and related adhesion focal tyrosine kinase. J Biol Chem 2003, 278:36661-36668.

39. Du QS, Ren XR, Xie Y, Wang Q, Mei L, Xiong WC: Inhibition of PYK2induced actin cytoskeleton reorganization, PYK2 autophosphorylation and focal adhesion targeting by FAK. J Cell Sci 2001, 114:2977-2987.

40. Jiang X, Jacamo R, Zhukova E, Sinnett-Smith J, Rozengurt E: RNA interference reveals a differential role of FAK and Pyk2 in cell migration, leading edge formation and increase in focal adhesions induced by LPA in intestinal epithelial cells. J Cell Physiol 2006, 207:816-828.

41. Lipinski CA, Tran NL, Bay C, Kloss J, McDonough WS, Beaudry C, Berens ME, Loftus JC: Differential role of proline-rich tyrosine kinase 2 and focal adhesion kinase in determining glioblastoma migration and proliferation. Mol Cancer Res 2003, 1:323-332.

42. Ilic D, Furuta Y, Kanazawa S, Takeda N, Sobue K, Nakatsuji N, Nomura S, Fujimoto J, Okada M, Yamamoto T: Reduced cell motility and enhanced focal adhesion contact formation in cells from FAK-deficient mice. Nature 1995, 539-544.

43. Streblow DN, Vomaske J, Smith P, Melnychuk R, Hall LA, Pancheva D, Smit M, Casarosa P, Schlaepfer DD, Nelson JA: Human cytomegalovirus chemokine US28 induced SMC migration is mediated by focal adhesion kinase and Src. J Biol Chem 2003, 278:50456-50465.

44. Melnychuk RM, Streblow DN, Smith PP, Hirsch AJ, Pancheva D, Nelson JA: Human Cytomegalovirus-Encoded G Protein-Coupled Receptor US28 Mediates Smooth Muscle Cell Migration through G\{alpha\}12. J Virol 2004, 78:8382-8391.

45. Hsia DA, Mitra SK, Hauck CR, Streblow DN, Nelson JA, llic D, Huang S, Li E, Nemerow GR, Leng J, et al: Differential regulation of cell motility and invasion by FAK. J Cell Biol 2003, 160:753-767.

46. Streblow DN, Orloff SL, Nelson JA: The HCMV chemokine receptor US28 is a potential target in vascular disease. Curr Drug Targets Infect Disord 2001, 1:151-158.

47. Owen JD, Ruest PJ, Fry DW, Hanks SK: Induced focal adhesion kinase (FAK) expression in FAK-null cells enhances cell spreading and migration 
requiring both auto- and activation loop phosphorylation sites and inhibits adhesion-dependent tyrosine phosphorylation of Pyk2. Mol Cell Biol 1999, 19:4806-4818.

48. Streblow DN, Soderberg-Naucler C, Vieira J, Smith P, Wakabayashi E, Ruchti F, Mattison K, Altschuler Y, Nelson JA: The human cytomegalovirus chemokine receptor US28 mediates vascular smooth muscle cell migration. Cell 1999, 99:511-520.

49. Ohanian V, Gatfield K, Ohanian J: Role of the actin cytoskeleton in Gprotein-coupled receptor activation of PYK2 and paxillin in vascular smooth muscle. Hypertension 2005, 46:93-99.

50. Xie J, Allen KH, Marguet A, Berghorn KA, Bliss SP, Navratil AM, Guan JL, Roberson MS: Analysis of the calcium-dependent regulation of prolinerich tyrosine kinase 2 by gonadotropin-releasing hormone. $\mathrm{Mol}$ Endocrinol 2008, 22:2322-2335.

51. Wang Q, Xie Y, Du QS, Wu XJ, Feng X, Mei L, McDonald JM, Xiong WC: Regulation of the formation of osteoclastic actin rings by proline-rich tyrosine kinase 2 interacting with gelsolin. J Cell Biol 2003, 160:565-575.

52. Rojas RJ, Yohe ME, Gershburg S, Kawano T, Kozasa T, Sondek J: Galphaq directly activates p63RhoGEF and Trio via a conserved extension of the Dbl homology-associated pleckstrin homology domain. J Biol Chem 2007, 282:29201-29210.

53. Dougherty MK, Ritt DA, Zhou M, Specht SI, Monson DM, Veenstra TD, Morrison DK: KSR2 is a calcineurin substrate that promotes ERK cascade activation in response to calcium signals. Mol Cell 2009, 34:652-662.

54. Miranda C, Roccato E, Raho G, Pagliardini S, Pierotti MA, Greco A: The TFG protein, involved in oncogenic rearrangements, interacts with TANK and NEMO, two proteins involved in the NF-kappaB pathway. J Cell Physiol 2006, 208:154-160

55. Shi CS, Kehrl JH: PYK2 links G(q)alpha and G(13)alpha signaling to NFkappa B activation. J Biol Chem 2001, 276:31845-31850.

56. Xi CX, Xiong F, Zhou Z, Mei L, Xiong WC: PYK2 interacts with MyD88 and regulates MyD88-mediated NF-kappaB activation in macrophages. Leukoc Biol 2010, 87:415-423.

57. Cobbs CS, Soroceanu L, Denham S, Zhang W, Britt WJ, Pieper R, Kraus MH Human cytomegalovirus induces cellular tyrosine kinase signaling and promotes glioma cell invasiveness. J Neurooncol 2007, 85:271-280.

58. Lipinski CA, Tran NL, Dooley A, Pang YP, Rohl C, Kloss J, Yang Z, McDonough W, Craig D, Berens ME, Loftus JC: Critical role of the FERM domain in Pyk2 stimulated glioma cell migration. Biochem Biophys Res Commun 2006, 349:939-947.

59. Lipinski CA, Tran NL, Menashi E, Rohl C, Kloss J, Bay RC, Berens ME, Loftus JC: The tyrosine kinase pyk2 promotes migration and invasion of glioma cells. Neoplasia 2005, 7:435-445.

60. Lipinski CA, Tran NL, Viso C, Kloss J, Yang Z, Berens ME, Loftus JC: Extended survival of Pyk2 or FAK deficient orthotopic glioma xenografts. Neurooncol 2008, 90:181-189.

61. Pyrko P, Schonthal AH, Hofman FM, Chen TC, Lee AS: The unfolded protein response regulator GRP78/BiP as a novel target for increasing chemosensitivity in malignant gliomas. Cancer Res 2007, 67:9809-9816.

62. Takano S, Wadhwa R, Yoshii Y, Nose T, Kaul SC, Mitsui Y: Elevated levels of mortalin expression in human brain tumors. Exp Cell Res 1997, 237:38-45

63. Vila-Carriles WH, Zhou ZH, Bubien JK, Fuller CM, Benos DJ: Participation of the chaperone $\mathrm{Hsc70}$ in the trafficking and functional expression of ASIC2 in glioma cells. J Biol Chem 2007, 282:34381-34391.

64. Zeise E, Kuhl N, Kunz J, Rensing L: Nuclear translocation of stress protein Hsc70 during S phase in rat C6 glioma cells. Cell Stress Chaperones 1998, 3:94-99.

65. Pu P, Zhang Z, Kang C, Jiang R, Jia Z, Wang G, Jiang $H$ : Downregulation of Wnt2 and beta-catenin by siRNA suppresses malignant glioma cell growth. Cancer Gene Ther 2009, 16:351-361.

66. Sareddy GR, Challa S, Panigrahi M, Babu PP: Wnt/beta-catenin/Tcf signaling pathway activation in malignant progression of rat gliomas induced by transplacental N-ethyl-N-nitrosourea exposure. Neurochem Res 2009, 34:1278-1288.

67. Gerthoffer WT: Mechanisms of Vascular Smooth Muscle Cell Migration Circ Res 2007, 100:607-621.

68. Yin G, Yan C, Berk BC: Angiotensin II signaling pathways mediated by tyrosine kinases. Int J Biochem Cell Biol 2003, 35:780-783.

69. Frank GD, Saito S, Motley ED, Sasaki T, Ohba M, Kuroki T, Inagami T, Equchi S: Requirement of $\mathrm{Ca}(2+)$ and PKCdelta for Janus kinase 2 activation by angiotensin II: involvement of PYK2. Mol Endocrinol 2002, 16:367-377.

70. Kostyukova AS: Tropomodulins and tropomodulin/tropomyosin interactions. Cell Mol Life Sci 2008, 65:563-569.

71. Fischer RS, Yarmola EG, Weber KL, Speicher KD, Speicher DW, Bubb MR, Fowler VM: Tropomodulin 3 binds to actin monomers. J Biol Chem 2006, 281:36454-36465

72. Gunning P, O'Neill G, Hardeman E: Tropomyosin-based regulation of the actin cytoskeleton in time and space. Physiol Rev 2008, 88:1-35.

73. Houle F, Rousseau S, Morrice N, Luc M, Mongrain S, Turner CE, Tanaka S, Moreau P, Huot J: Extracellular signal-regulated kinase mediates phosphorylation of tropomyosin-1 to promote cytoskeleton remodeling in response to oxidative stress: impact on membrane blebbing. $\mathrm{Mol} \mathrm{BiO}$ Cell 2003, 14:1418-1432.

74. Kuwabara K, Nakaoka T, Sato K, Nishishita T, Sasaki T, Yamashita N: Differential regulation of cell migration and proliferation through proline-rich tyrosine kinase 2 in endothelial cells. Endocrinology 2004, 145:3324-3330.

75. Soderberg-Naucler C: Does cytomegalovirus play a causative role in the development of various inflammatory diseases and cancer? J Intern Med 2006, 259:219-246

76. Louis DN, Ongaki H, Wiestler OD, Cavenee WK, Burger PC, Jouvet A, Scheithauer BW, Kleihues P: The 2007 WHO classification of tumours of the central nervous system. Acta Neuropathol 2007, 114:97-109.

77. Mitchell DA, Xie W, Schmittling R, Learn C, Friedman A, McLendon RE, Sampson $\mathrm{JH}$ : Sensitive detection of human cytomegalovirus in tumors and peripheral blood of patients diagnosed with glioblastoma. Neuro Oncol 2008, 10:10-18.

78. Mitchell D, Archer GE, Bigner DD, Friedman HS, Lally-Goss D, Herndon JE I, McGehee S, McLendon R, Reardon DA, Sampson JH: Efficacy of a phase II vaccine targeting Cytomegalovirus antigens in newly diagnosed GBM. Clin Oncol 2008, 26.

79. Roelle S, Grosse R, Buech T, Chubanov V, Gudermann T: Essential role of Pyk2 and Src kinase activation in neuropeptide-induced proliferation of small cell lung cancer cells. Oncogene 2008, 27:1737-1748.

80. Zhang S, Qiu X, Gu Y, Wang E: Up-regulation of proline-rich tyrosine kinase 2 in non-small cell lung cancer. Lung Cancer 2008, 62(3):295-301.

81. liizumi M, Bandyopadhyay S, Pai SK, Watabe M, Hirota S, Hosobe S, Tsukada T, Miura K, Saito K, Furuta E, et al: RhoC promotes metastasis via activation of the Pyk2 pathway in prostate cancer. Cancer Res 2008, 68:7613-7620

82. Picascia A, Stanzione R, Chieffi P, Kisslinger A, Dikic I, Tramontano D: Proline-rich tyrosine kinase 2 regulates proliferation and differentiation of prostate cells. Mol Cell Endocrinol 2002, 186:81-87.

83. Stanzione R, Picascia A, Chieffi $P$, Imbimbo C, Palmieri A, Mirone $V$, Staibano S, Franco R, De Rosa G, Schlessinger J, Tramontano D: Variations of proline-rich kinase Pyk2 expression correlate with prostate cancer progression. Lab Invest 2001, 81:51-59

84. Loftus JC, Yang Z, Tran NL, Kloss J, Viso C, Berens ME, Lipinski CA: The Pyk2 FERM domain as a target to inhibit glioma migration. Mol Cancer Ther 2009, 8:1505-1514.

85. van Buul JD, Anthony EC, Fernandez-Borja M, Burridge K, Hordijk PL: Proline-rich tyrosine kinase 2 (Pyk2) mediates vascular endothelialcadherin-based cell-cell adhesion by regulating beta-catenin tyrosine phosphorylation. J Biol Chem 2005, 280:21129-21136.

86. Daugaard M, Rohde M, Jaattela M: The heat shock protein 70 family: Highly homologous proteins with overlapping and distinct functions. FEBS Lett 2007, 581:3702-3710.

87. Mizukoshi E, Suzuki M, Misono T, Loupatov A, Munekata E, Kaul SC, Wadhwa R, Imamura T: Cell-cycle dependent tyrosine phosphorylation on mortalin regulates its interaction with fibroblast growth factor-1. Biochem Biophys Res Commun 2001, 280:1203-1209.

88. Spinardi L, Witke W: Gelsolin and diseases. Subcell Biochem 2007, 45:55-69.

89. Bucki R, Levental I, Kulakowska A, Janmey PA: Plasma gelsolin: function, prognostic value, and potential therapeutic use. Curr Protein Pept Sc 2008, 9:541-551.

90. Lindberg U, Schutt CE, Goldman RD, Nyakern-Meazza M, Hillberg L, Rathje LS, Grenklo S: Tropomyosins regulate the impact of actin binding proteins on actin filaments. Adv Exp Med Biol 2008, 644:223-231.

91. Bach CT, Creed S, Zhong J, Mahmassani M, Schevzov G, Stehn J, Cowell LN, Naumanen P, Lappalainen P, Gunning PW, O'Neill GM: Tropomyosin 
isoform expression regulates the transition of adhesions to determine cell speed and direction. Mol Cell Biol 2009, 29:1506-1514.

92. Ivaska J, Pallari HM, Nevo J, Eriksson JE: Novel functions of vimentin in cell adhesion, migration, and signaling. Exp Cell Res 2007, 313:2050-2062.

93. Dupre DJ, Robitaille M, Rebois RV, Hebert TE: The role of Gbetagamma subunits in the organization, assembly, and function of GPCR signaling complexes. Annu Rev Pharmacol Toxicol 2009, 49:31-56.

94. Costanzo-Garvey DL, Pfluger PT, Dougherty MK, Stock JL, Boehm M, Chaika O, Fernandez MR, Fisher K, Kortum RL, Hong EG, et al: KSR2 is an essential regulator of AMP kinase, energy expenditure, and insulin sensitivity. Cell Me tab 2009, 10:366-378.

95. Fujisawa K, Madaule P, Ishizaki T, Watanabe G, Bito H, Saito Y, Hall A, Narumiya S: Different regions of Rho determine Rho-selective binding of different classes of Rho target molecules. J Biol Chem 1998, 273:18943-18949.

96. Rossman KL, Der CJ, Sondek J: GEF means go: turning on RHO GTPases with guanine nucleotide-exchange factors. Nat Rev Mol Cell Biol 2005, 6:167-180.

97. Bliznyukov OP, Kozmin LD, Vysotskaya LL, Golenkov AK, Tishchenko VM, Samoylovich MP, Klimovich VB: Human immunoglobulin light chains lambda form amyloid fibrils and granular aggregates in solution. Biochemistry (Mosc) 2005, 70:458-466.

98. Lin YM, Ono K, Satoh S, Ishiguro H, Fujita M, Miwa N, Tanaka T, Tsunoda T, Yang KC, Nakamura Y, Furukawa Y: Identification of AF17 as a downstream gene of the beta-catenin/T-cell factor pathway and its involvement in colorectal carcinogenesis. Cancer Res 2001, 61:6345-6349.

99. Barber LJ, Youds JL, Ward JD, Mcllwraith MJ, O'Neil NJ, Petalcorin MI, Martin JS, Collis SJ, Cantor SB, Auclair M, et al: RTEL1 maintains genomic stability by suppressing homologous recombination. Cell 2008, 135:261-271

100. Nakanishi H, Takai Y: Roles of nectins in cell adhesion, migration and polarization. Biol Chem 2004, 385:885-892

101. Dechamps C, Bach S, Portetelle D, Vandenbol M: The Tre2 oncoprotein, implicated in Ewing's sarcoma, interacts with two components of the cytoskeleton. Biotechnol Lett 2006, 28:223-231.

102. Jaleel M, McBride A, Lizcano JM, Deak M, Toth R, Morrice NA, Alessi DR: Identification of the sucrose non-fermenting related kinase SNRK, as a novel LKB1 substrate. FEBS Lett 2005, 579:1417-1423.

103. Tomsig JL, Creutz CE: Copines: a ubiquitous family of $\mathrm{Ca}(2+)$-dependent phospholipid-binding proteins. Cell Mol Life Sci 2002, 59:1467-1477.

104. Grove M, Demyanenko G, Echarri A, Zipfel PA, Quiroz ME, Rodriguiz RM, Playford M, Martensen SA, Robinson MR, Wetsel WC, et al: ABI2-deficient mice exhibit defective cell migration, aberrant dendritic spine morphogenesis, and deficits in learning and memory. Mol Cell Biol 2004, 24:10905-10922.

105. Shete S, Hosking FJ, Robertson LB, Dobbins SE, Sanson M, Malmer B, Simon M, Marie Y, Boisselier B, Delattre JY, et al: Genome-wide association study identifies five susceptibility loci for glioma. Nat Genet 2009, 41:899-904.

106. Wrensch M, Jenkins RB, Chang JS, Yeh RF, Xiao Y, Decker PA, Ballman KV, Berger M, Buckner JC, Chang S, et al: Variants in the CDKN2B and RTEL1 regions are associated with high-grade glioma susceptibility. Nat Genet 2009, 41:905-908.

107. Shen Q, Zheng X, McNutt MA, Guang L, Sun Y, Wang J, Gong Y, Hou L, Zhang B: NAT10, a nucleolar protein, localizes to the midbody and regulates cytokinesis and acetylation of microtubules. Exp Cell Res 2009, 315:1653-1667.

108. Filleur S, Hirsch J, Wille A, Schon M, Sell C, Shearer MH, Nelius T, Wieland I: INTS6/DICE1 inhibits growth of human androgen-independent prostate cancer cells by altering the cell cycle profile and Wnt signaling. Cancer Cell Int 2009, 9:28.

109. Le Mercier M, Mathieu V, Haibe-Kains B, Bontempi G, Mijatovic T, Decaestecker C, Kiss R, Lefranc F: Knocking down galectin 1 in human hs683 glioblastoma cells impairs both angiogenesis and endoplasmic reticulum stress responses. J Neuropathol Exp Neurol 2008, 67:456-469.

110. Yi X, Luk JM, Lee NP, Peng J, Leng X, Guan XY, Lau GK, Beretta L, Fan ST: Association of mortalin (HSPA9) with liver cancer metastasis and prediction for early tumor recurrence. Mol Cell Proteomics 2008, 7:315-325.

\section{doi:10.1186/2042-4280-1-2}

Cite this article as: Vomaske et al:: HCMV pUS28 initiates pro-migratory signaling via activation of Pyk2 kinase. Herpesviridae 2010 1:2.

\section{Submit your next manuscript to BioMed Central and take full advantage of:}

- Convenient online submission

- Thorough peer review

- No space constraints or color figure charges

- Immediate publication on acceptance

- Inclusion in PubMed, CAS, Scopus and Google Scholar

- Research which is freely available for redistribution

Submit your manuscript at www.biomedcentral.com/submit
Biomed Central 